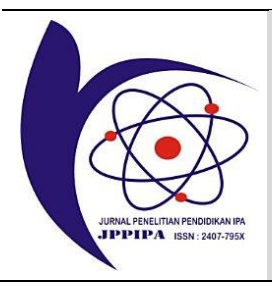

\title{
Development of a PjBL Model Learning Program Plan based on a STEM Approach to Improve Students' Science Process Skills
}

\author{
Muhammad Syukri1 ${ }^{*}$, Dewi Agusti Yanti², Elmi Mahzum³ ${ }^{3}$ Abdul Hamid ${ }^{4}$ \\ 1,2,3,4 Physics Education, Faculty of Teacher Training and Education, Universitas Syiah Kuala, Banda Aceh, Indonesia
}

DOI: $\underline{10.29303 / \text { ippipa.v7i2.680 }}$

\section{Article Info}

Received: February 28th, 2021

Revised: April 17th, 2021

Accepted: April 21 th 2021

\begin{abstract}
The purpose of the research is to developing Learning Program Plan (LPP) with a PjBL model based on the STEM approach to improve the students' science process skills in physics learning. This research refers to the development of ADDIE, namely: 1) Analysis, 2) Design, 3) Development, 4) Implementation and 5) Evaluation. The worthiness of the Learning Program Plan is measure by the result of the Learning Program Plan validation and the responding of the subject is 7 teachers. The result of all the Learning Program Plan showing average value is 4 , that is the valid category. The research design used in the study is Research and Developing (R\&D). The research subject is 3 physics teachers at SMA Negeri 5 Banda Aceh, 1 physics teacher at SMA Negeri 1 Lawe Alas, 1 physics teacher at MA Negeri 1 Aceh Tenggara, and 2 physics teachers at SMA 3 Kutacane. Data of the research are questionnaires that are given to the teacher. Data management is carried out by Statistik analysis Likert scale. Questionnaire of the result showed until 89\%. From both measures are found the development of Learning Program Plan model PjBL that teacher assessment result to Learning Program Plan with an average score 4.45 with the overall percentage based STEM approach to improving science process student skills in physics learning.
\end{abstract}

Keywords: PjBL Model; STEM Approach; Science Process Skills.

Citation: $\quad$ Syukri, M., Yanti, D., Mahzum, E., \& Hamid, A. (2021). Development of a PjBL Model Learning Program Plan based on a STEM Approach to Improve Students' Science Process Skills. Jurnal Penelitian Pendidikan IPA, 7(2), 269274. doi:https://doi.org/10.29303/ippipa.v7i2.680

\section{Introduction}

Advances of technology in the field of education producing teachers and students demanded competence to have relevant teaching and learning in the 21st century. Science education plays an important role in design a reliable and quality young generation in facing the challenges in the 21st century. Science education is a combination of several science education sciences including physics, biology, and chemistry. But nowadays, the main problem in the world education is regarding the quality of education, especially the quality of science skills, which is still very low in the process (Nurhadi \& Senduk, 2004).
The weak quality of education stated by The Work Bank that there is a comparison of access and quality of educational achievement in several countries. The output of education in Indonesia still low in levels of thinking, namely knowledge, understanding, and application. Meanwhile, in thinking to high levels such as analysis, evaluation, and creativity, are still very lowly.

The Factors that influence the low science process skills of students in Indonesia include the learning model applied by the teacher and the teaching materials used by students (Kurnia, 2014). In accordance with the research conducted by Jack (2013), two factors cause low science process skills, namely a 
low scientific background and a lack of laboratory infrastructure. It is necessary to strive for a learning process that can accompany change, to motivate students in develop their reasoning power in planning and solving problems faced by providing direct experience by carrying out a series of scientific processes and linking them between science and technology.

Based on the results of observations and interviews that have been surveyed with one of the physics teachers, that is known if the implementation of physics learning at school only emphasizes understanding of concepts, mastery of theory, and discussion of questions. So that students have not been able to practice science process skills such as formulating problems, formulating hypotheses, observing, concluding, interpreting, and other activities that can train science process skills, to make science process skills that exist in students not yet visible. This problem is a real condition of students during the physics learning process, although not all schools experience the same situation. According to the observations of Wiyanto (2006), it shows that in general physics learning tends to be monotonous with low scientific activity. This situation is a problem that causes the students' low science process skills (Suyono, 2011).

A great solution to solve the problem of science process skills is using a learning model that could help students to improve science process skills. The model that is considered appropriate to solve this problem is the Project Based Learning (PjBL) model.

According to Afriana (2016), Project-based learning is a student-centered knowledge model and provides meaningful learning experiences for students. Several PjBL studies can improve cognitive learning outcomes (Baran, 2010), form attitudes and behaviors that care for the environment (Kilinc, 2010), science process skills (Ozer, 2012), and effective learning (Cook, 2012). Project-based learning is more appropriate in interdisciplinary learning because it naturally involves many different academic skills, such as reading, writing, and mathematics, and is appropriate in building conceptual understanding through assimilation of different subjects (Capraro, 2013). So that expectation with the model of $\mathrm{PjBl}$, that would of student improve skill in science learned.

The application of science many found in imposing technology, so an approach is needed that can provide alternatives for students to be able to face the 21st century which is full of challenges. According to Stohlmann (2012), the relationship between science and technology and other sciences cannot be separated in science learning. STEM (Science, Technology, Engineering, and Mathematics) are disciplines that are closely related to one another. Science requires mathematics as a tool in data processing, while technology and engineering are applications of science. The STEM approach to learning is expected to produce meaningful learning for students through the systematic integration of knowledge, concepts, and skills. Some of the benefits of the STEM approach make students better able to solve problems innovators, inventors, independent, logical thinkers, and technological literacy (Sasmita et al., 2021; Syukri et al., 2018).

As stated by Sartika (2019) "Components in STEM, Science is a study of natural phenomena that involves observation and measurement, as a vehicle to objectively explain the ever-changing nature. There are several main domains of science at the primary and secondary education levels, namely physics, biology, chemistry, and earth and space sciences.

Technology is about human innovations that are used to modify nature to meet human needs and desires, thus making life better and safer. Technologies allow humans to travel quickly, communicate directly with people in distant places, find healthy food and safety tools.

The problem identification in this study is how the process and results of the development of the PjBL model based on the STEM approach improving students' science process skills in physics learning. It is known that physics is one of science learning which is intended to pay attention to the order of the universe and emphasizes providing a direct experience that can help students to gain a deeper understanding of their surroundings (Dewi, 2018; Syukri et al., 2017; Susilawati et al., 2020).

Physics is also one of the subjects tested in the field of science held by PISA and TIMSS, so that researcher interested in developing it with the title "Development of RPP Model Project-Based Learning Based on STEM Approach to Improve Students' Science Process Skills".

\section{Method}

The type of study is research and development or commonly abbreviated as R\&D with the research model used referring to the ADDIE development model that has been modified by the researcher, which consists of 5 (five) steps, namely: (1) analysis (analyze), (2) design, (3) development, (4) implementation and (5) evaluation.

The stages of the ADDIE development pattern are modified according to the current conditions in the field, namely the Covid-19 outbreak which causes no direct learning process, namely: 
1. In the analysis phase (analysis), the analysis activities include analysis and curriculum analysis. Researchers at this stage analyze the things that are needed in the process of developing lesson plans in accordance with the learning objectives. The analysis stage is used to obtain information about the necessary or one of the reasons for requiring to develop RPP PjBL based on the STEM approach to improving students' science process skills.

2. The second phase is design, at this phase the researcher designs the product that will be developed in accordance with being required. At the design stage, the PjBL model based on the STEM approach was compiled.

3. A development phase is a follow-up act to design that has been made. The follow-up is in the form of validation carried out by lecturers who are experts in their fields. This stage serves to the view of the RPP worthiness that has been designed can be used. After receiving an assessment, the Learning Program Plan will be revised according to input from the validator.

4. The fourth stage is the implementation phase, at this stage, the Learning Program Plan which has been developed and validated by experts is worthy of being tested on a predetermined subject. However, due to the Covid-19 pandemic that has been going on for a long time in some areas, students have to learn at home and it is difficult for researchers to conduct research. So that the researchers diverted the research by distributing questionnaires to 1 physics teacher at SMA 1 Lawe Alas, 1 physics teacher at MAN 1 Aceh Tenggara, and 2 physics teacher at SMA 3 Kutacane

5. The fifth phase is the phase of evaluation product, at this stage to measure the achievement of the lesson plan development seen from the average percentage of the validation and assessment of the teachers.

The subjects of this research are 1 physics teacher at SMA 1 Lawe Alas, 1 physics teacher at MAN 1 Aceh Tenggara, and 2 physics teachers at SMA 3 Kutacane. The instruments used is the form of RPP validation sheets by experts and teacher response questionnaires. The Analyze of Validation Sheet to Feasibility Learning Program Plan Validation sheet of Learning Program Plan is used to obtain data on the validity of the Learning Program Plan. This assessment sheet will be given to lecturers who have expertise specifications on the material being developed, Learning Program Plan assessment sheets are measured using very valid, valid, Less valid, and invalid criteria (Sugiyono, 2009).

The criteria for evaluating the feasibility of the Learning Program Plan are expressed in a percentage calculated based on the distribution of the total score obtained by the maximum score (Sudijono, 2008: 43).

Based on this equation, the percentage value range for the validity of the Learning Program Plan is in accordance with the table below:

Tabel 1. Percentage Qualification

\begin{tabular}{lll}
\hline No & Score range & Qualification \\
\hline 1 & $82 \%<\mathrm{P} \leq 100 \%$ & Valid \\
2 & $63 \%<\mathrm{P} \leq 81 \%$ & Valid \\
3 & $44 \%<\mathrm{P} \leq 62 \%$ & Invalid \\
4 & $25 \%<\mathrm{P} \leq 43 \%$ & Invalid \\
\hline
\end{tabular}

(Source: Sudjana, 2005)

This technique is using to analyze the response data/teacher responses to the developing class program. The teacher response questionnaire was prepared with five alternative answers, namely Very Agreeable (VA), Agreeable (A), Disagree (DA), Totally Disagree (TDA). According to Sudijono (2008: 43), the calculation uses the formula:

$$
\mathrm{P}=\mathrm{f} / \mathrm{N} \times 100 \%
$$

Explanation:

p: The number of percentages,

$\mathrm{f}:$ The frequency, and

$\mathrm{N}$ : the number of respondents.

The result of categorizing the percentages of respondents' answers into scale categories can be determined based on the value scale (Husein, 2011). The following scores interpret the percentage of the overall questionnaire answers using the interpretation based on Arikunto (1996):

Tabel 2. Score (percentage) questionnaire

\begin{tabular}{lll}
\hline No & Option & Score \\
\hline 1 & $0 \%<\mathrm{P} \leq 25 \%$ & Not Feasible \\
2 & $26 \%<\mathrm{P} \leq 50 \%$ & Worthy \\
3 & $51 \%<\mathrm{P} \leq 75 \%$ & Feasible \\
4 & $76 \%<\mathrm{P} \leq 100 \%$ & Very Feasible \\
\hline
\end{tabular}

(Source: Arikunto, 1996)

\section{Result and Discussion}

The production of product in this research is the RPP Model Project Based Learning based on the STEM approach to improve students' science process skills, with the ADDIE stage, namely :

1. The analysis phase, this conducted in accordance with the requirement analysis and curriculum analysis that applies at schools.

2. The design stage is designing the lesson plan according to the Project-Based Learning model based on the STEM approach. 
3. The development stage that is the RPP assessment implement by 2 validators according to predetermined criteria.

4. Implementation Stage of distributing teacher response questionnaires related to lesson plans that have been developed to 7 teachers in SMA.

5. Evaluation, the percentage of Learning Program Plan based on the assessment by the teacher is $89 \%$, which is in the very feasible category.

In this discussion, the development producing of the product that found in the suitability of the objectives of developing lesson plans, namely to improve the science process skills of students. The development of this lesson plan is expected that students can be more active in learning activities both individually and in groups, and students are more interested in learning and understanding the material and its special concepts in dynamic fluid material.

The development of Learning Program Plan before being used as teaching materials were first validated by 2 expert lecturers. As stated by Sugiyono (2015), "that validation activities to assess new products that are designed must be carried out by experienced experts". In this study, validation was conducted through one of the STEM expert lecturers and an expert in the field of Physics Education learning tools at Syiah Kuala University.

Validation activities are conducted to view are the development of Learning Program Plan refers to a theoretical foundation and contains components that are interrelated with one another. As stated by Sukmadinata (2005), "that validation activities to assess the appropriateness of the basic concepts or theories used are very important to conducted".

Based on the results of the Learning Program Plan validation test, it was obtained a percentage of $82 \%$ with valid criteria. In the validating of the Learning Program Plan, there were several comments and suggestions given by the validator. As in the media and learning resources section, must be including LKPD. This is intended for teachers who are still focused in implement the learning process. As the function of Learning Program Plan stated by Kunandar (2011), "The Learning Program Plan is used as a reference for teachers to carry out the learning process so that it is more focused so that learning can run effectively and efficiently".

Based on the questionnaire given to each teacher, the percentage of eligibility of the results of the teacher's assessment of the lesson plan was $89 \%$ and included in the very feasible criteria. Some respondents disagreed with the Learning Program Plan project-based learning model related to indicators arranged according to $\mathrm{KD}$, this was because $\mathrm{KD}$ was included in the C4 criteria, so the preparation of indicators had to be equivalent or in accordance with KD. According to the opinion of Mulyana (2011), "that indicators are behaviors that can be measured and observed to show the achievement of certain basic competencies that become a reference for subject assessment. Majid (2013) states, "that indicators are specific basic competencies that can be used as a measure to determine the achievement of learning outcomes.

Respondents also disagreed with the steps of learning activities that reflected the activities of the PjBL model and the first steps of the PjBL model were the syntax of PjBL itself, namely determining the basic questions and planning the project. This is because some respondents do not understand the model as a whole so that few of the respondents give values regarding the Project Based Learning (PjBL) model in the Learning Program Plan. Based on Komalasari's statement (2011: 57), "The learning model is basically a form of learning that is illustrated from beginning to end which is typically presented by the teacher, in other words, the learning model is a package or frame of the application of an approach, method, and learning technique."

The opposite occurs in the questionnaire stated that the development of the Learning Program Plan section contains elements of the relationship between learning material and STEM (Science, Technology, Engineering, and Mathematics) in accordance with the material analysis table, respondents already understand a few about the STEM approach itself, especially the researchers also provide a brief pre-study explanation, particularly regarding the STEM approach.

In the statement, media learning and resources support the achievement of indicators because the media used already exists at the school. In accordance with the statement of Steffi Adam and Muhammad Taufik Syastra (2015) "Media learning is everything of both physical and technical in the learning process that can help teachers to make it easier to convey subject matter to students so that it makes it easier to achieve the learning indicators that have been formulated".

Whereas in the remaining statements the respondents gave a moderate value from the score, as a whole the respondents agreed with these statements. It can be said that the development of PBjL model learning tools based on the STEM approach has met the appropriate criteria to be given to students in learning and can be used in improving students' science process skills. 


\section{Conclusion}

The results of the research it was found that the development of PjBL model RPP based on the STEM approach results in an overall percentage of $82 \%$ with valid criteria from the validator and the teacher's assessment of the RPP and would obtain an overall percentage of $89 \%$ with very feasible criteria. Thus it can be concluded that the RPP project-based learning model based on the STEM approach is feasible to be used to improve students' science process skills in a dynamic fluid material.

\section{References}

Afriana, J., Permanasari, A., \& Fitriani, A. (2016). Penerapan Project Based Learning Terintegrasi STEM untuk Meningkatkan literasi sains siswa Ditinjau dari Gender. Jurnal Inovasi Pendidikan IPA, 2(2), 202-212. doi: https://doi.org/10.21831/jipi.v2i2.8561 [Indonesian]

Arikunto. (1996). Prosedur Penelitian. Jakarta, Indonesia: Rineka Cipta. [Indonesian]

Baran, M. \& Maskan, A. (2010). The Effectof ProjectBased Learning On pre-Service Physics teachers' Electrostatic Achievements. Cypriot Journal of Educational Sciences, 5, 243-257. https:// www.semanticscholar.org/

Capraro, R. M., Capraro, M. M., Morgan, J. R., \& Slough, S. W. (2013). STEM Project-Based Learning: An Integrated Science, Technology, Engineering, and Mathematics (STEM) Approach Retrieved from: https://link.springer.com/book/10.1007/97894-6209-143-6

Cook, K. Buck, G. Park Rogers, M. (2012). Preparing Biology Teachers To Teach Evolution In A Project-Based Approach. Science Educator, 21(2), 18-30. Retrieved from: https://eric.ed.gov/?id=EJ997503

Dewi, M., Kurniawati, I. \& Suwarma, I. R. (2018). The application of learning physics using the STEM approach to improve students' problem-solving skills in dynamic electricity material. Paper presented at the Quantum National Seminar, Department of Physics Education, FPMIPA, University of Pendidikan Indonesia, Bandung. Retrieved from: http://repository.upi.edu/36336/

Husein, U. (2011). Metode Penelitian untuk Skripsi dan Tesis Bisnis Edisi II. Jakarta, Indonesia: Raja Grafindo Persada. [Indonesian]

Jack, G.U. (2013). The Influence of Identified Studemt and School Variables on Student Science Process
Skill Acquision, Journal of Education and Practice. 4 (5), 16-22 Retrieved from: https://www.semanticscholar.org/paper/TheInfluence-of-Identified-Student-and-School-onJack/8971fc91ba542158241722037929d71922ebc0 $\underline{\text { bf }}$

Kılınc, A. (2010). Can project-Based Learning Close the Gap. Turkish student teachers and Proen Vironmental Behaviours, 5(4), 495-509, Retrieved from:http://79.123.211.16/xmlui/handle/20.500 .12513/181\#sthash.R5ge1SD7.dpbs

Komalasari. (2011). Pembelajaran Konstektual. Bandung, Indonesia: Refika Aditama [Indonesian]

Kunandar. (2011). Guru Profesional (Implementasi Kurikulum Tingkat Satuan Pendidikan dan Sukses dalam Sertifikasi Guru). Jakarta, Indonesia: Raja Grafindo Persada. [Indonesian]

Kurnia, F., Zulherman, \& Fathurohman, A. (2014). Analisis Bahan Ajar Fisika SMA Kelas XI di Kecamatan Indralaya Utara Berdasarkan Kategori Literasi Sains. Jurnal Inovasi dan Pembelajaran Fisika, 1(1), 43-47 doi: https://doi.org/10.36706/jipf.v1i1.1263 [Indonesian]

Majid, A. (2013). Strategi Pembelajaran.: Bandung, Indonesia: Rosdakarya. [Indonesian]

Mulyana, Deddy. (2011). Ilmu Komunikasi. Bandung, Indonesia: Rosdakarya. [Indonesian]

Nurhadi \& Senduk. (2004). Pembelajaran Kontekstual dan Penerapannya dalam KBK. Malang, Indonesia: Universitas Negeri Malang Pres. [Indonesian]

Ozer, D.Z. \& Ozkan, M. (2012). The Effectof the project based learning onthe science process skills of the prospective teachers of science. Journal of Turkish Science Education. 9(3), 131-136. Retrieved from: https://www.researchgate.net/publication/419 26481

Sartika, D. (2019). Pentingnya Pendidikan Berbasis STEM dalam Kurikulum 2013. Retrieved from: http://ejournal.mandala.nursa.org/index.php/J ISIP/index [Indonesian]

Sasmita, D., Adlim, M., Gani, A., \& Syukri, M. (2021). Implementation of STEM-based Student Worksheet to Increase Student Entrepreneurial Innovation through the Development of Candied Nutmeg Products. Jurnal Penelitian Pendidikan IPA, 7(1), 112-120. doi: 10.29303/jppipa.v7i1.551

Stohlmann, M., Moore, T. J., \& Roehrig, G. H. (2012). Considerations for Teaching Integrated STEM Education. Journal of Pre-College Engineering Education Research (J-PEER), 2(1), Article 4. https://doi.org/10.5703/1288284314653

Sudjana. (2005). Metode Statistika. Bandung, Indonesia: Tarsito. [Indonesian] 
Sudijono. (2008). Pengantar Statistik Pendidikan. Jakarta, Indonesia: Grafindo Persada. [Indonesian]

Sugiyono. (2015). Metode Penelitian Kombinasi (mix Methods). Bandung, Indonesia: Alvabeta. [Indonesian]

Sukmadinata, N. S. (2005). Metode Penelitian Pendidikan. Bandung, Indonesia: PT Remaja Rosdakarya. [Indonesian]

Susilawati, S., Doyan, A., Artayasa, P., Soeprianto, H., \& Harjono, A. (2020). Analysis of Validation Development Science Learning Tools using Guided Inquiry Model Assisted by Real Media to Improve the Understanding Concepts and Science Process Skills of Students. Jurnal Penelitian Pendidikan IPA, 7(1), 41-44 doi: https://doi.org/10.29303/ippipa.v7i1.473

Suyono \& Hariyanto. (2011). Belajar dan Pembelajaran. Bandung, Indonesia: Rosdakarya Offset. [Indonesian]

Syukri, M., Halim, L., \& Mohtar, L. E. (2017). Engineering design process: cultivating creativity skills through development of science technical product. Jurnal Fizik Malaysia, 38(1), 10055-10065. Retrieved from: http://ifm.org.my/jurnal-fizikmalaysia/engineering-design-processcultivating-creativity-through-science-technical

Syukri, M., Halim, L., Mohtar, L., \& Soewarno, S. (2018). The Impact of Engineering Design Process in Teaching and Learning to Enhance Students' Science Problem-Solving Skills. Jurnal Pendidikan IPA Indonesia, 7(1), 66-75. doi:https://doi.org/10.15294/ipii.v7i1.12297

Wiyanto. (2006). Potret Pembelajaran Sains di SMP dan SMA. Journal Pendidikan Fisika Indonesia. 4(2), 6366. doi: https://doi.org/10.15294/jpfi.v4i2.170 